\title{
RANCANG BANGUN SISTEM INFORMASI PENJUALAN PADA TOKO BANGUNAN ATT MENGGUNAKAN METODE PEMODELAN UML
}

\section{Fitri Yunita}

Program Studi Sistem Informasi, Fakultas Teknik dan Ilmu Komputer Universitasi Islam Indragiri (UNISI)

Jl. Propinsi, Parit 1 Tembilahan Hulu, Tembilahan, Riau, Indonesia

Email :fitriyun@gmail.com

\begin{abstract}
ABSTRAK
Toko bangunan ATT merupakan toko bangunan yang berdomisili di wilayah Tembilahan Hulu, berdiri 11 Juni 2012 dan dirintis oleh bapak Joni Hartono, SE. Toko ini menjual alat-alat bangunan dan listrik berstandar Nasional. Dalam proses dagang ini, Pendokumentasian data seperti data barang yang masuk dicatat di dalam buku. Namun, untuk data transaksi penjualan di toko ini, tidak dicatat di buku laporan transaksi. Transaksi penjualan yang berlangsung, hanya diingat saja, tanpa dicatat transaksinya. Padahal data-data tersebut suatu waktu akan dibutuhkan untuk membuat laporan penjualan. Pada toko ini, sistem informasi penjualan juga belum tergambarkan secara visual, sehingga pihak toko tidak mengetahi secara detail bagaimana gambaran umum sistem yang berjalan di tokonya dan bagaimana gambaran proses yang terjadi dalam kegiatan jual beli. Untuk mempermudah pihak toko mengelola data barang dan data transaksi, maka perlu dirancang sebuah sistem informasi penjualan. Dengan dibangunnya sistem informasi penjualan ini, diharapkan mampu mengatasi persoalan yang ada di Toko Bangunan ATT, dapat membantu memberikan laporan data transaksi penjualan saat dibutuhkan dan juga sebagai sarana pembelajaran bagi peneliti dalam melakukan kajian ilmiah.
\end{abstract}

Kata Kunci :Rancang bagun sistem informasi penjualan, pemodelan UML 


\section{PENDAHULUAN}

Tumbuh dan berkembangnya budaya pemakaian produk berlabel SNI (Standar Nasional Indonesia) oleh warga negara Indonesia membawa dampak positif. Hal ini bisa kita lihat pada kondisi fisik perumahan, perkantoran, gedung-gedung fasilitas umum, DLL. Dalam pembangunannya, mereka telah memanfaatkan alat-alat bangunan dan listrik berlabel SNI. Dengan demikian, keselamatan kerja para pekerja bangunan lebih besar, karena ditunjang oleh alat-alat bangunan dan listrik yang berstandar nasional Indonesia. Pemerintah tentu menyambut baik perilaku masyarakat dalam pemakaian alat-alat bangunan dan listrik berstandar nasional Indonesia ini.

Toko bangunan ATT merupakan toko bangunan yang berdomisili di wilayah Tembilahan Hulu, berdiri 11 Juni 2012 dan dirintis oleh bapak Joni Hartono, SE. Toko ini menjual alat-alat bangunan dan listrik berstandar Nasional. Dalam proses dagang ini, Pendokumentasian data seperti data barang yang masuk dicatat di dalam buku. Namun, untuk data transaksi penjualan di toko ini, tidak dicatat di buku laporan transaksi. Transaksi penjualan yang berlangsung, hanya diingat saja, tanpa dicatat transaksinya. Padahal data-data tersebut suatu waktu akan dibutuhkan untuk membuat laporan penjualan. Pada toko ini, sistem informasi penjualan juga belum tergambarkan secara visual, sehingga pihak toko tidak mengetahi secara detail bagaimana gambaran umum sistem yang berjalan di tokonya dan bagaimana gambaran proses yang terjadi dalam kegiatan jual beli.

Untuk mempermudah pihak toko mengelola data barang dan data transaksi, maka perlu dirancang sebuah sistem informasi penjualan. Dengan dibangunnya sistem informasi penjualan ini, diharapkan mampu mengatasi persoalan yang ada di Toko Bangunan ATT.

\section{TINJAUAN PUSTAKA}

\subsection{Sistem}

Sistem adalah kumpulan atau himpunan dari unsur atau variabel-variabel yang saling terkait, saling berinteraksi, dan saling tergantung satu sama lain untuk mencapai tujuan. Selain itu sistem juga dapat didefinisikan sebagai sekumpulan objek-objek yang saling berelasi dan berinteraksi, serta hubungan antar objek bisa dilihat sebagai satu kesatuan yang dirancang untuk mencapai satu tujuan yang telah ditetapkan. (Tohari, 2014).

Setiap sistem meiliki elemen-elemen yang membentuk sistem tersebut, yaitu tujuan (goal), masukan (input), proses (process), keluaran (output), mekanisme pengendalian (control mechanism) dan umpan balik (feedback). Selain itu, sistem juga berinteraksi dengan lingkungan dan memiliki batasan system (Gambar 1).

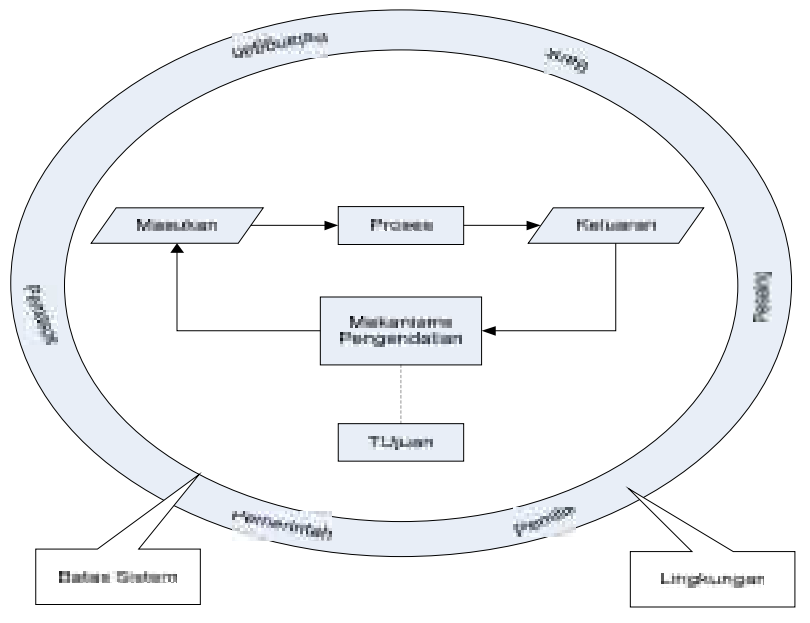

Gambar 1 Sistem perusahaan dan elemenelemennya

\subsection{Informasi}

Sistem informasi dapat dianalogikan sebagai sebuah permintaan (demand) dari masyarakat industri, ketika kebutuhan akan sarana pengolahan data dan komunikasi 
yang cepat dan murah (menembus ruang dan waktu). (Tohari, 2014). informasi sebagai data yang telah diproses sedemikian rupa sehingga meningkatkan pengetahuan seseorang yang menggunakan data tersebut. Menggambarkan pengolahan data menjadi informasi dan pemakaian informasi untuk mengambil keputusan, hingga akhirnya dari tindakan hasil pengambilan keputusan tersebut dihasilkan data kembali. Bisa dilihat pada Gambar 2 dibawah ini.

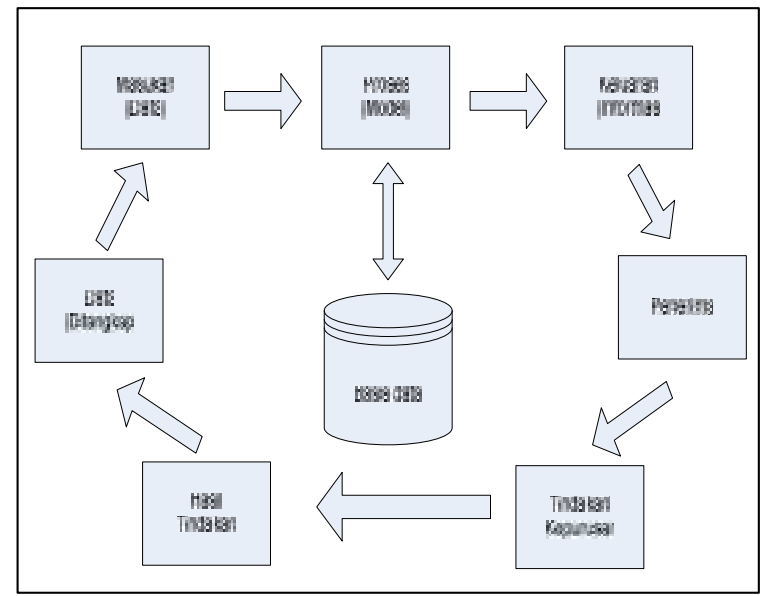

\section{Gambar 2 Siklus informasi}

\subsection{Konsep Pemodelan Sistem}

Siklus hidup pengembangan sistem didefinisikan sebagai serangkaian aktivitas yang dilaksanakan oleh profesional dan pemakai sistem informasi untuk mengembangkan dan mengimplementasikan sistem informasi.

Siklus hidup pengembangan sistem informasi saat ini terbagi atas enam fase, yaitu :

a. Perencanaan sistem

b. Analisis sistem

c. Desain sistem

d. Implementasi sistem

e. Operasi dan pemeliharaan / perawatan sistem

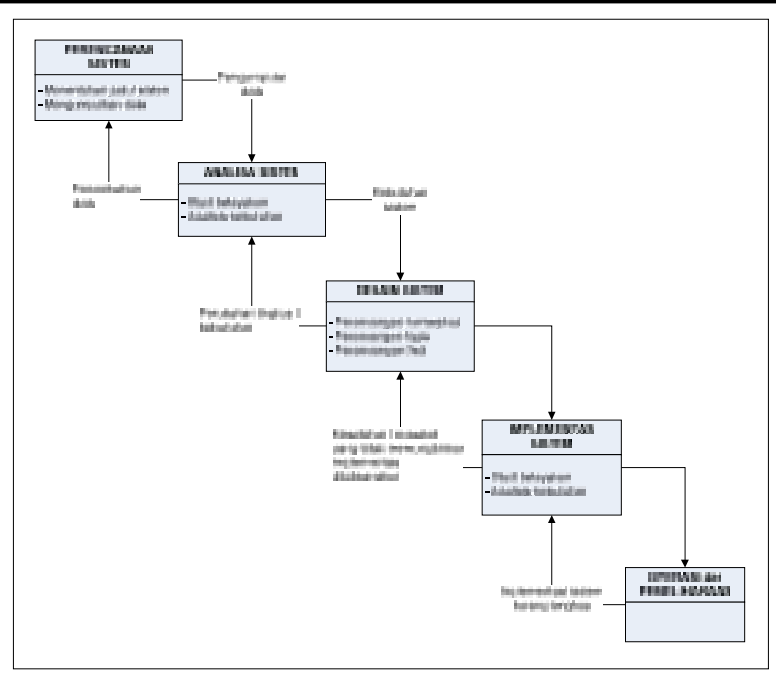

\section{Gambar 3 Fase Siklus Hidup Pengembangan Sistem}

\subsection{Disgaram UML}

UML (Unifield Modeling Language) adalah bahasa pemodelan untuk sistem atau perangkat lunak yang berparadigma berorientasi objek. Pemodelan (modeling) sesungguhnya digunakan untuk penyederhanaan permasalahanpermasalahan yang kompleks sedemikian rupa sehingga lebih mudah dipelajari dan dipahami.(Nugroho, 2010).

Ada banyak diagram dalam UML (Unified Modeling Language), penulis akan membahas diagram yang digunakan dalam melakukan analisa dan rancangan sistem pengolahan data penjualan sebagai berikut:

\section{a) Use Case Diagram}

Use Case menggambarkan fungsi tertentu dalam suatu sistem berupa komponen, kejadian atau kelas. Sedangkan mengartikanuse case sebagai urutan langkah-langkah yang secara tindakan saling terkait (scnario), baik terotomatisasi maupun secara manual, untuk tujuan melengkapi satu tugas bisnis tunggal. Komponen-komponen pembentuk diagram use case adalah sebagai berikut: 

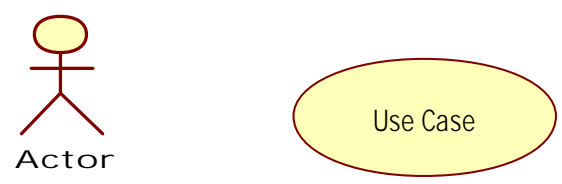

Gambar 4 Actor dan Use Case

Aktor (actor), menggambarkan pihak-pihak yang berperan dalam sistem.Use Case, aktivitas/sarana yang disiapkan oleh bisnis/sistem.Hubungan (link), aktor mana saja yang terlibat dalam use case ini.

Ada beberapa relasi yang terdapat pada use case diagram, yaitu :

a. Association, menghubungkan link antar element.

b. Generalization, disebut juga pewarisan (inheritance), sebuah elemen dapat merupakan spesialisasi dari elemen lainnya.

c. Dependency, sebuah element bergantung dalam beberapa cara ke element lainnya.

d. Aggregation, bentuk association dimana sebuah elemen berisi elemen lainnya.

Tipe relasi yang mungkin terjadi pada use case diagram:

a < include>>, yaitu kelakuan yang harus terpenuhi agar sebuah event dapat terjadi, dimana pada kondisi ini sebuah use case adalah bagian dari usecase lainnya.

b < <extends>>, kelakuan yang hanya berjalan di bawah kondisi tertentu seperti menggerakkan peringatan.

c <<communicates $>>$, merupakan pilihan selama asosiasi hanya tipe relationship yang dibolehkan antara aktor dan use case.

\section{b) Activity Diagram}

Diagram aktivitas adalah tipe khusus dari diagram status yang memperlihatkan aliran dari suatu aktivitas ke aktivitas lainnya dalam suatu sistem. Diagram ini terutama penting dalam pemodelan fungsifungsi suatu sistem dan memberi tekanan pada aliran kendali antar objek.

\section{METODOLOGI PENELITIAN}

Metode penelitian merupakan cara atau teknik yang digunakan dalam rancangan bagun sistem informasi ini. Adapun metode yang diakukan dalam penelitian ini adalah sebagai berikut:

\subsection{Metode pengumpulan data}

Metode pengumpulan data yang digunakan dalam analisis dan perancangan sistem informasi ini adalah :

a. Observasi, yaitu melakukan pengamatan langsung di tempat penelitian, untuk mengamati aktivitas yang terjadi pada Toko Bangunan ATT. Observasi ini juga dilakukan untuk mengamati sistem yang sedang berjalan pada Toko Bangunan ATT.

b. Studi Literatur, yaitu mencari sumbersumber tulisan berupa buku maupun sumber lainnya yang dijadikan data pendukung dalam penelitian dan perancangan sistem.

c. Wawancara, yaitu melakukan dialog tanya jawab secara langsung kepada Bapak Joni Hartono, SE sebagi manager di Toko Bangunan ATT untuk memperoleh data dan informasi yang berhubungan dengan objek dan permasalahan yang akan diteliti.

\subsection{Metode analisa data}

Siklus hidup pengembangan sistem model waterfall berfungsi untuk menggambarkan tahapan utama dan langkah-langkah dari setiap tahapan. Secara garis besar terbagi dalam 3 kegiatan utama, yaitu : 


\section{Analisa Sistem}

Tahapan analisa digunakan untuk melihat dan menganalisa sistem pada Toko Bangunan ATT. Apakah sistem tersebut layak untuk dikembangkan dan dibangun sistem informasi penjualan yang baru atau tidak.

\section{Desain}

Tahapan perancangan (design) ini ialah tahapan merancang desain sistem yang baru supaya dapat menyelesaikan masalahmasalah yang ada pada Toko Bangunan ATT. Berikut tahapan perancangan :

a. Perancangan Keluaran

Perancangan keluaran bertujuan untuk menentukan keluaran/output sistem informasi penjualan pada Toko Bangunan ATT. Keluaran tersebut berupa tampilan layar dan laporan.

b. Perancangan Masukan

Perancangan masukan bertujuan untuk menentukan data masukan yang akan digunakan sebagai data untuk diproses oleh sistem. Data masukan tersebut dapat berupa faktur/data transaksi dan laporan barang masuk.

c. Perancangan File

Perancangan file dalam bagian perancangan basis data pada sistem informasi penjualan ini dengan menggunakan pemodelan UML (Unified Modeling Language).

3. Implementasi

Tahap implementasi mempunyai beberapa tujuan, yaitu untuk melakukan kegiatan spesifikasi rancangan logical kedalam kegiatan yang sebenarnya dari sistem informasi yang akan dibangun. Kemudian mengimplementasikan sistem yang baru tersebut kedalam bahasa pemograman visual basic 6.0

\subsection{Analisa SWOT}

Analisa SWOT digunakan pada penelitian ini untuk mendapatkan perbandingan antara faktor internal, yaitu kekuatan (strenghs) dan kelemahan (weaknesses) dengan faktor ekternal, yaitu peluang (oportunities) dan ancaman (threats).

1 .

nalisa internal. Analisa internal adalah upaya untuk mengenali dan mendeskripsikan berbagai aspek yang ada di dalam internal perusahaan/toko. Misalnya :

a. agaimana keadaan karyawan ?

b. agaimana keadaan toko ?

Jadi, dengan analisa internal dapat menghasilkan informasi tentang kekuatan (strenghs) dan kelemahan (weaknesses).

Tabel 1 Analisa Internal

\begin{tabular}{|l|l|}
\hline \multicolumn{1}{|c|}{ Kekuatan } & \multicolumn{2}{c|}{ Kelemahan } \\
\hline Lokasi toko strategis & $\begin{array}{l}\text { Halaman toko kurang } \\
\text { luas }\end{array}$ \\
\hline $\begin{array}{l}\text { Pelayanan } \\
\text { berkualitas }\end{array}$ & $\begin{array}{l}\text { Karyawan bagian } \\
\text { antar barang kurang }\end{array}$ \\
\hline Harga relatif murah & $\begin{array}{l}\text { Barang tidak diberi } \\
\text { label harga }\end{array}$ \\
\hline $\begin{array}{l}\text { Transaksi cukup } \\
\text { banyak }\end{array}$ & $\begin{array}{l}\text { Transaksi tidak } \\
\text { dicatat/tidak dibuat } \\
\text { laporannya }\end{array}$ \\
\hline
\end{tabular}

2.

nalisa eksternal perusahaan. Analisa eksternal adalah upaya untuk mengenali dan mendeskripsikan berbagai hal, situasi, dan kondisi di luar toko yang ada kaitannya dengan kegiatan operasional perusahaan.

Misalnya :

a. engaruh naiknya harga BBM terhadap penjualan.

Tabel 2 Analisa Eksternal

\begin{tabular}{|c|c|}
\hline Peluang & Ancaman \\
\hline $\begin{array}{ll}\text { Pembelian viar akan } \\
\text { mempermudah akses } \\
\text { antar barang } \\
\text { tempat pembeli }\end{array}$ & $\begin{array}{l}\text { Ada pesaing yang } \\
\text { tidak } \\
\text { jauh/dekat dengan } \\
\text { toko }\end{array}$ \\
\hline
\end{tabular}




\begin{tabular}{|c|c|}
\hline $\begin{array}{l}\text { Penambahan } \\
\text { karyawan akan } \\
\text { membantu pelayanan } \\
\text { dan akan } \\
\text { meningkatkan } \\
\text { pendapatan } \\
\text { perusahaan/toko }\end{array}$ & $\begin{array}{l}\text { Naiknya harga } \\
\text { BBM membuat } \\
\text { harga barang juga } \\
\text { naik, hal ini dapat } \\
\text { menurunkan daya } \\
\text { beli konsumen }\end{array}$ \\
\hline $\begin{array}{l}\text { Pembuatan software } \\
\text { penjualan akan } \\
\text { membantu mengelola } \\
\text { data barang dan data } \\
\text { transaksi, termasuk } \\
\text { membuat laporan }\end{array}$ & $\begin{array}{lr}\text { Pelanggan } & \text { yang } \\
\text { memiliki } & \text { kepekaan } \\
\text { terhadap } & \text { harga } \\
\text { barang, } & \text { dapat } \\
\text { pindah kepesaing } & \\
\text { yang menawarkan } & \\
\text { harga lebih murah }\end{array}$ \\
\hline
\end{tabular}

\section{HASIL DAN PEMBAHASAN 4.1. Pembuatan UML}

a. Definisi Actor

Definisi actor pada perancangan sistem baru Toko Bangunan ATT Tembilahan dijelaskan pada tabel 3 berikut.

Tabel 3 Definisi Aktor

\begin{tabular}{|c|l|l|}
\hline No. & \multicolumn{1}{|c|}{ Actor } & \multicolumn{1}{|c|}{ Deskripsi } \\
\hline 1 & Pembeli & Membeli barang \\
\hline 2 & $\begin{array}{l}\text { Karyawan } \\
\text { Bagian } \\
\text { Marketing }\end{array}$ & $\begin{array}{l}\text { Melayani pembeli. } \\
\text { Membantu } \\
\text { pembeli/konsumen } \\
\text { menemukan barang } \\
\text { yang dicari }\end{array}$ \\
\hline No. & Actor & \multicolumn{1}{|c|}{ Deskripsi } \\
\hline 3 & ADM & $\begin{array}{l}\text { Bertugas mengelola } \\
\text { data penjualan seperti } \\
\text { entri data barang masuk } \\
\text { dan membuat laporan. }\end{array}$ \\
\hline 4 & Pimpinan & $\begin{array}{l}\text { Menerima laporan dari } \\
\text { ADM toko }\end{array}$ \\
\hline
\end{tabular}

Use Case merupakan bentuk gambaran umum sistem yang akan dibuat.
Gambaran Use Casediagram dapat dilihat pada gambar 5 .

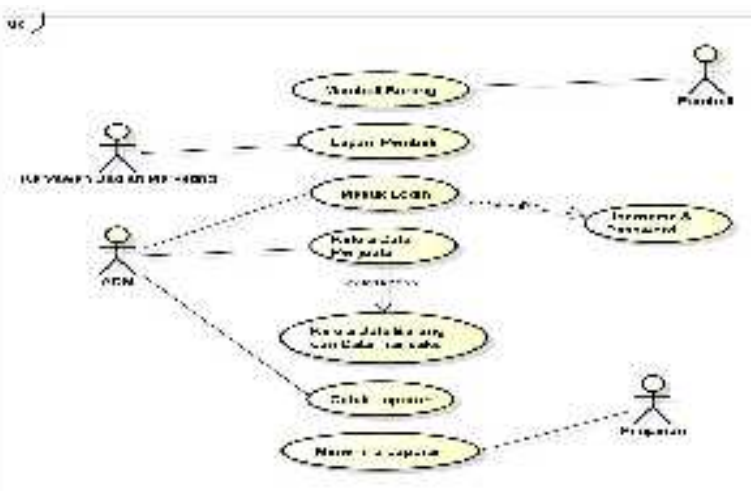

Gambar 5Use case Diagram

Diagram Use Case di atas menggambarkan sistem informasi penjualan secara keseluruhan pada Toko Bangunan ATT. Pada sistem ini, aktivitas-aktivitas yang terjadi digambarkan dengan Use Case, kemudian sebagai pelakunya digambarkan dengan actor.

\section{Pembuatan Activity Diagram}

Sebuah activity diagram menunjukkan proses bisnis atau proses perangkat lunak sebagai aliran kerja melalui serangkaian tindakan. Orang, komponen perangkat lunak, atau komputer dapat melakukan tindakan ini.

\section{a. Diagram Aktivitas Login}

Bentuk diagram aktivitas login pada sistem informasi penjualan Toko Bangunan ATT dapat dilihat pada gambar 3.4 berikut ini. 


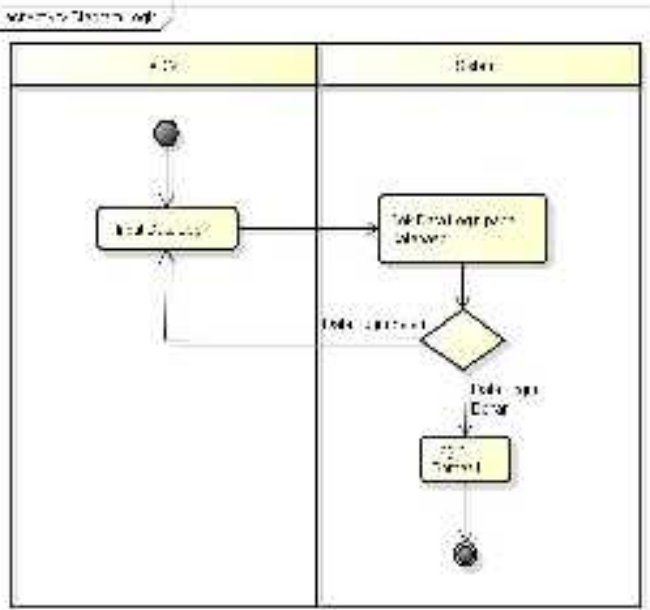

\section{Gambar 6 Diagram Aktivitas Login}

Aktivitas login dimulai dengan memasukkan data login, yaitu username dan password. Kemudian sistem akan melakukan validasi data. Apabila terjadi kesalahan dalam memasukkan login, maka sistem akan menampilkan pesan kesalahan dan meminta pengguna memasukkan kembali username dan password yang benar. Ababila data login sudah benar, maka sistem akan menampilan menu utama.

\section{b. Diagram Aktivitas Input Data Barang \\ Bentuk diagram aktivitas input data} barang pada sistem informasi penjualan Toko Bangunan ATT dapat dilihat pada gambar 7 berikut ini.

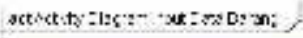

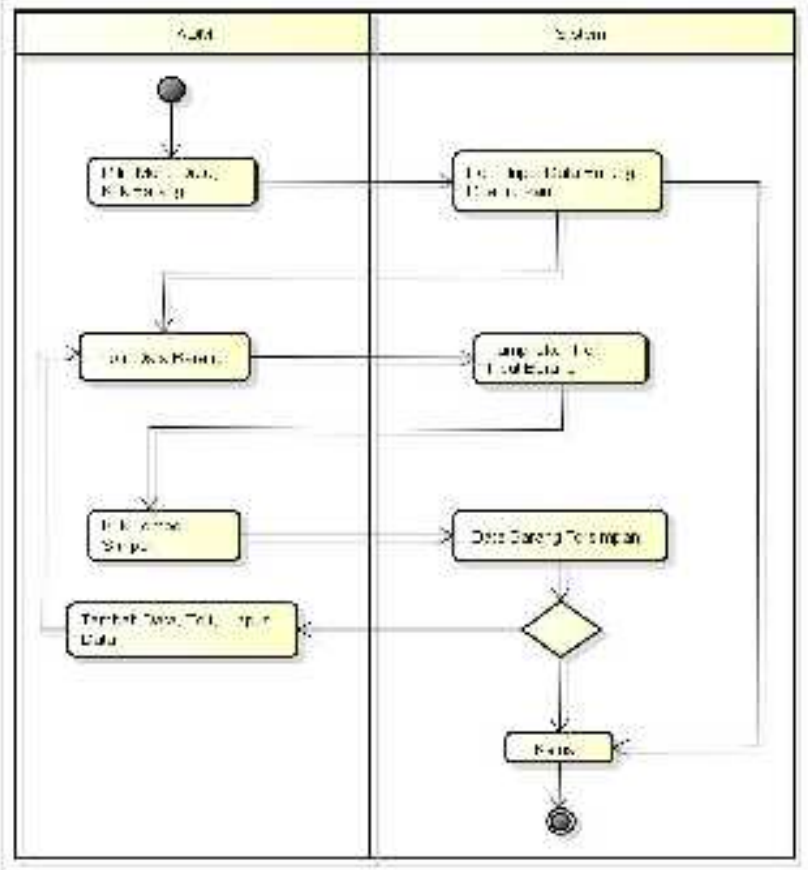

\section{Gambar 7 Diagram Aktivitas Input Data Barang}

Aktivitas input data barang dimulai dari memilih menu data, klik barang, kemudian sistem akan menampilkan form input data barang. Setelah form barang ditampilakan, baru siadmin bisa menginputkan data barang dan kemudian menyinpannya. Pada form ini terdapat tombol simpan, batal, edit, hapus, dan tutup.

\section{c. Diagram Aktivitas Penjualan Barang \\ Bentuk diagram aktivitas penjualan barang pada sistem informasi penjualan Toko Bangunan ATT dapat dilihat pada gambar 8 berikut ini.}




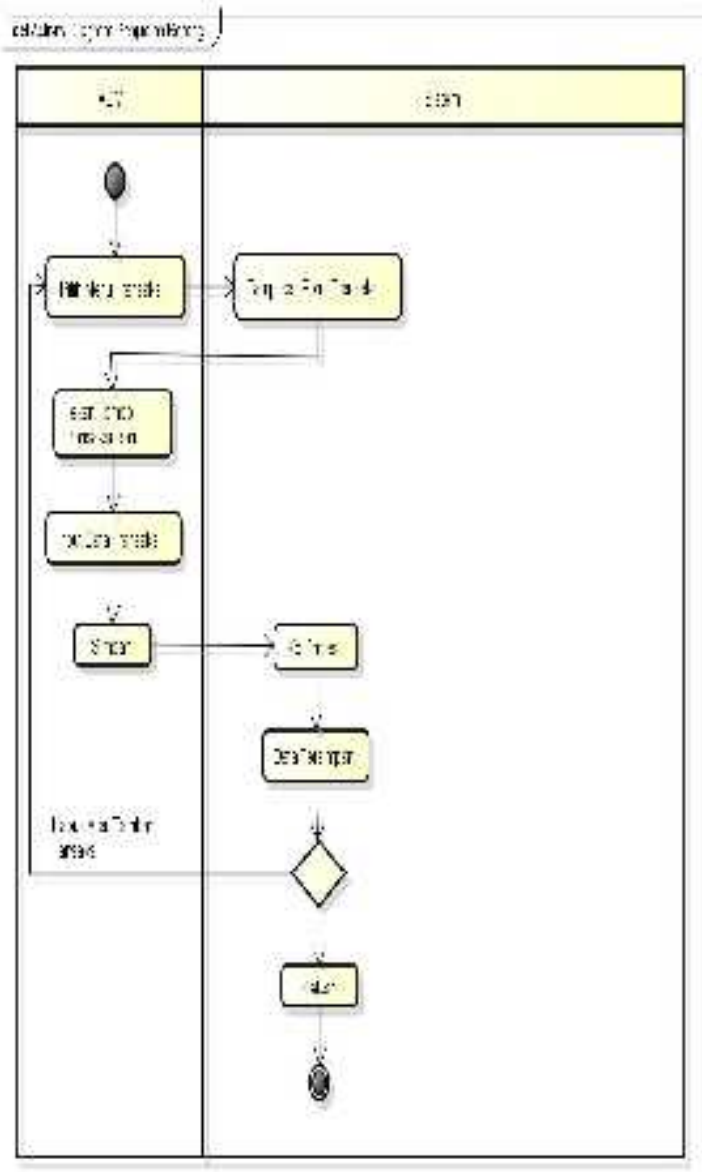

\section{Gambar 8 Diagram Aktivitas Penjualan Barang}

Aktivitas penjualan barang ini dimulai pilih menu transaksi oleh ADM, kemudian sistem akan menampilkan menu transaksi dan admin dapat menginputkan data transaksi. Pada form transaksi ini juga siadmin menginputkan uang yang dibayarkan pembeli, dan sistem akan memprosesnya, lalu menampilkan uang kembalinya. Setelah itu, bila konsumen menambah transaksi baru, maka siadmin akan kembali pada proses penginputan data pembelian barang. Setelah transaksi dari konsumen cukup atau tidak ada penambahan transaksi dari seorang konsumen, siadmin akan menyimpan data transaksi dengan menklik tombol simpan. Aktivitas ini diakhiri dengan simpan dan keluar.

\section{d. Diagram Aktivitas Cetak Laporan}

Bentuk diagram aktivitas cetak laporan pada sistem informasi penjualan Toko Bangunan ATT dapat dilihat pada gambar 9 berikut ini.

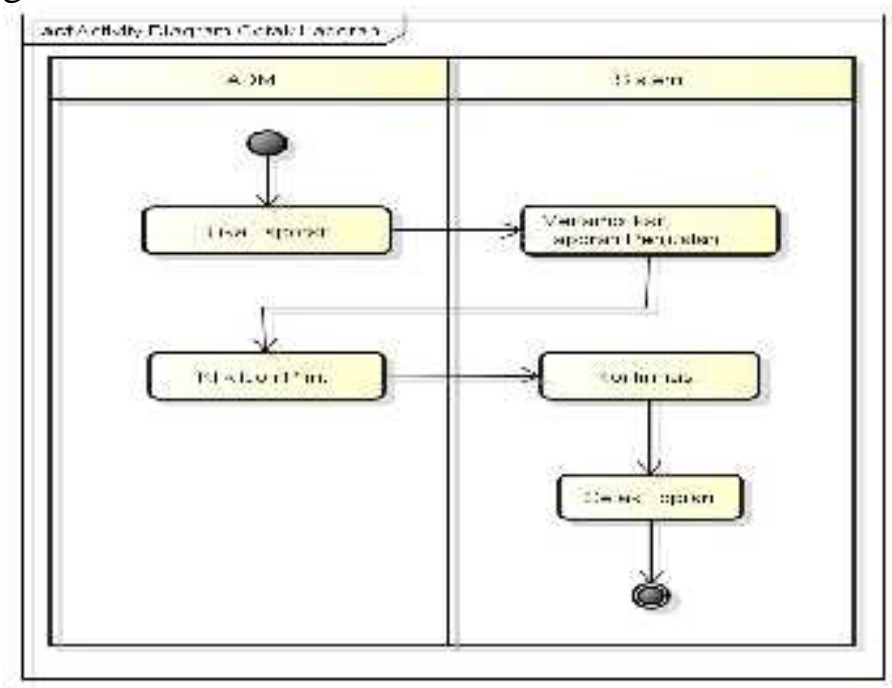

\section{Gambar 9 Diagram Aktivitas Cetak Laporan}

Aktivitas mencetak laporan dimulai dengan memilih menu cetak laporan, kemudian sistem akan menampilkan form interface/antarmuka. Admin memilih laporan bulan apa yang akan ditampilkan laporannya, kemudian admin akan mengkonfirmasinya dengan mengklik tombol ok. Sistem akan menunggu perintah cetak laporan dari admin. Apabila admin telah konfrimasi print/cetak, sistem akan mencetak laporan.

\subsection{Implementasi Program}

Implementasi program menampilkan form-form aplikasi yang dibuat menggunakan Microsoft Visual Basic 6.0 dan dihubungkan menggunakan database MySQL dan Crystal Report 10.

\section{Halaman Login}

Form login dalam aplikasi ni merupakan pintu utama untuk masuk 
kedalam halaman menu utama, bertindak sebagai pengaman aplikasi, agar aplikasi ini tidak bisa diakses oleh pihak yang tidak berhak, maka setiap pengguna harus entri usename dan passworduntuk masuk kesistem.

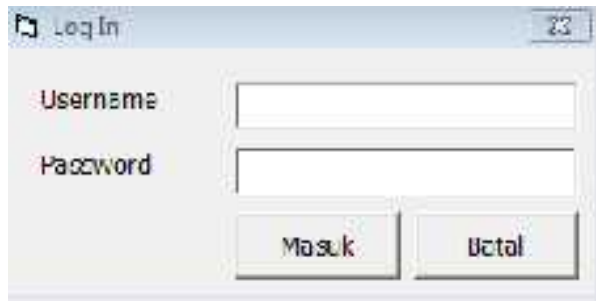

\section{Gambar 10 Halaman Login}

\section{Halaman Menu Utama}

Halaman menu utama merupakan halaman induk dari aplikasi ini, dimana halaman menu utama ini berisikan menumenu yang menghubungkan ke modulmodul program lainnya. Pada menu utama ini, terdapat sub menu, yaitu : data, transaksi, laporan, dan exit.

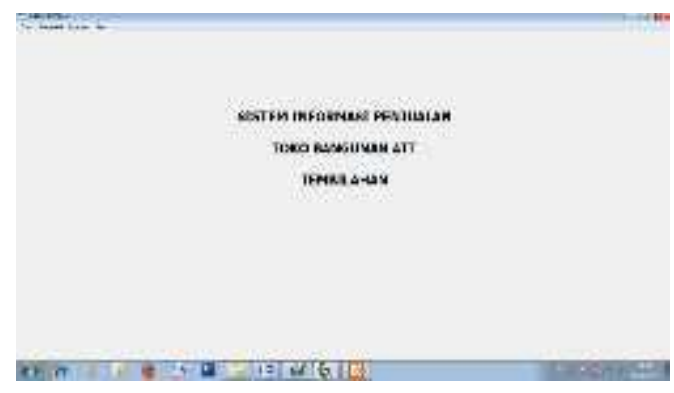

Gambar 11 Halaman Menu Utama

\section{Halaman Tambah Data Barang}

Halaman Tambah data barang ini merupakan halaman yang digunakan untuk menambahkan data barang. Berisikan kode_barang, nama_barang, jumlah, dan harga.

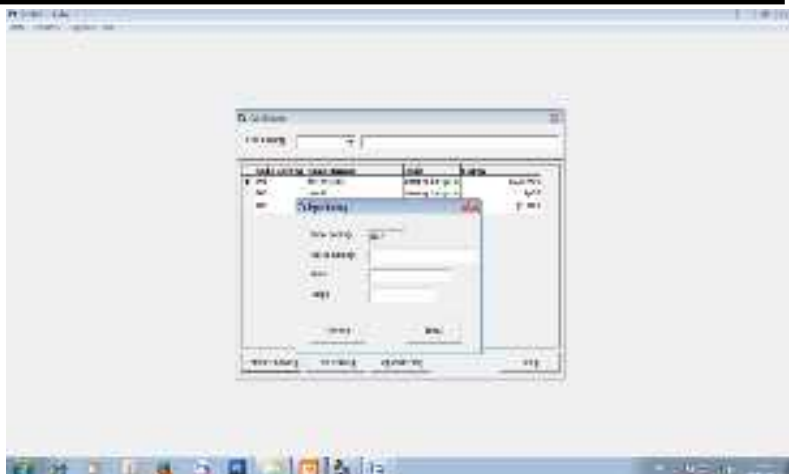

\section{Gambar 12 Halaman Tambah Data Barang}

\section{Halaman Tambah Data Penjualan}

Halaman Tambah data penjualan ini merupakan halaman yang digunakan untuk menambahkan data yang berhubungan dengan penjualan. Terdiri dari tombol Simpan yang berguna untuk proses menyimpan data penjualan.

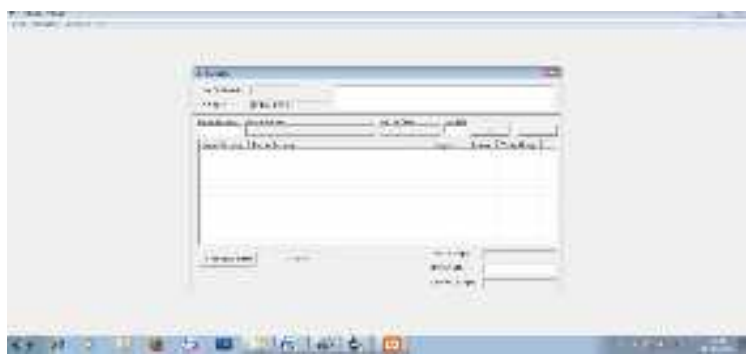

\section{Gambar 13 Halaman Tambah Data Penjualan (Transaksi)}

\section{Laporan Penjualan}

Laporan data penjualan merupakan hasil dari Sistem Informasi penjualan.

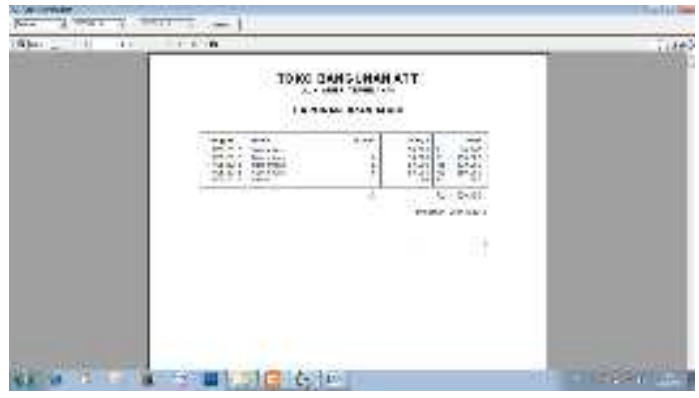

Gambar 13 Laporan Penjualan 


\section{PENUTUP}

\section{$5.1 \quad$ Kesimpulan}

Berdasarkan hasil kajian ilmiah yang dilakukan, kesimpulan dari penelitian ini adalah sebagai berikut :

1. Sistem informasi penjualan dapat mencatat transaksi-transaksi penjualan dan dapat langsung melihat laporannya per periode.

2. Informasi yang didapatkan dari program penjualan adalah didapatkan jumlah transaksi yang terjadi dan jumlah uangnya.

\subsection{Saran}

1. Program aplikasi ini kiranya bisa diterapkan, supaya penyimpanan dan pencarian data penjualan dapat dilakukan secara efektif dan efesien.

2. Output ini sebaiknya dilakukan secara berkala agar pengecekan laporan dapat dilakukan secara maksimal.

\section{REFERENSI}

Ardianto, E., \& Lusiana, V. (2014). Rancang Bangun Aplikasi Pengolah Gambar Digital untuk Segmentasi Otomatis Lokasi Objek Angka pada Meter Listrik, 1-12.

Kristanto, A. (2007). Perancangan Sistem Informasi dan Aplikasinya.

AndriKristanto,2008.Perancangansisteminfo rmasidanaplikasinya. Yogyakarta: Gava Media

Abdul Kadir, 2009.

Dasarperancangandanimplementas i.Yogyakarta: Andi

Hendrianto, D. E. (2014). Pembuatan Sistem Informasi Perpustakaan Berbasis Website Pada Sekolah Menegah Pertama Negeri 1

Sutabri, T. (2012). Analisis Sistem Informasi. Yogyakarta: Andi.

Rosa, \& Shalahuddin, M. (2015). Rekayasa Perangkat Lunak. Bandung: Informatika.

Tohari. (2014). Analisa Serta Perancangan Sistem Informasi Melalui UML. Yogyakarta: ANDI.

Nugroho, A. (2010). Rekayasa Perangkat Lunak Berorientasi Objek dengan Metode USDP (Unified Software Development Process). Yogyakarta: Penerbit Andi. 